\title{
Agrivoltaics in Ontario Canada: Promise and Policy
}

\author{
Joshua M. Pearce ${ }^{1,2 *}$
}
1 Department of Electrical \& Computer Engineering, Western University, London, ON, N6A 5B9, Canada; joshua.pearce@uwo.ca
2 Ivey Business School, Western University, London, ON, N6G 0N1, Canada
* Correspondence: e-mail@e-mail.com; Tel.: (optional; include country code; if there are multiple correspond- ing authors, add author initials)

\begin{abstract}
Well-intentioned regulations to protect Canada's most productive farmland restrict largescale solar photovoltaic (PV) development. The recent innovation of agrivoltaics, which is the codevelopment of land for both PV and agriculture, makes these regulations obsolete. Burgeoning agrivoltaics research has shown agricultural benefits including increased yield for a wide range of crops, plant protection from excess solar energy and hail, improved water conservation while maintaining agricultural employment and local food supplies. In addition, the renewable electricity generation decreases greenhouse gas emissions while increasing farm revenue. As Canada in general, and Ontario in particular, is at a strategic disadvantage in agricultural without agrivoltaics, this study investigates the policy changes necessary to capitalize on the benefits of using agrivoltaics in Ontario. Land use policies in Ontario are reviewed. Then, three case studies (peppers, sweet corn and winter wheat) are analyzed for agrivoltaic potential in Ontario. These results are analyzed in conjunction with potential policies that would continue to protect the green-belt of the Golden Horseshoe, while enabling agrivoltaics in Ontario. Four agrivoltaic policy areas are discussed: increased research and development, enhanced education/public awareness, mechanisms to support Canada's farmers converting to agrivoltaics and using agrivoltaics as a potential source of trade surplus with the U.S.
\end{abstract}

Keywords: agriculture; agrivoltaic; Greater Golden Horseshoe; Canada; energy policy; farming; Ontario; photovoltaic; solar energy

\section{Introduction}

Solar photovoltaic (PV) system costs have declined $[1,2]$ to the point that solar electricity production is now normally the least costly electricity source globally [3,4]. Throughout Canada, grid-connected PV systems are at grid-parity or beyond with the return on investment (ROI) of PV applications varying by province and utility [5]. PV can even be used to economically subsidize heat pumps to enable profitable electrification of gas-based heating in Ontario [6]. Unsurprisingly, PV electricity production in Canada continues to grow although it makes up less than $1 \%$ of electricity generation, while Ontario is the dominant province for PV deployment with approximately $94 \%$ of Canada's total cumulative installed capacity [5].

Canadian PV growth is good for the environment as PV is a well-established sustainable energy source [7] having been shown to be net energy producers for the last 20 years [8]. Energy conversion efficiencies for PV have actually increased [9] to the point that the energy payback time is less than a year [10]. These benefits also come with challenges such as the need of large land surface areas to power high-population-density cities, which are normally supplied by rural areas used for agricultural production [11]. Globally most people live in cities [12]. For example, the four largest urban regions in Canada - Southern Vancouver Island, the Lower Mainland, the Calgary-Edmonton corridor, and the Extended Golden Horseshoe - make up more than half (51\%) of the population of Canada [13]. Siting conflicts over land use were once relegated to wind farm development [14-17], but are increasingly becoming a barrier to large-scale PV projects as residents worry about 
interference with agricultural production [18-21]. Globally, land-use conflicts would be expected to increase as population increases $1.15 \%$ per annum [22]. Food production must increase by $70 \%$ from 2005 to 2050 to feed the anticipated 9.1 billion people that will make up the global population [23], so understandably decision makers do not want to make policies that decrease food production in addition to protecting the pastoral legacy of Canada's rural areas. Past efforts to use food crop land for ethanol production increased global food costs and global hunger [24-27]. In Canada, the population growth rate is also changing constantly [28], and careful attention to protecting Ontario's croplands have been regulated $[29,30]$. A "Greenbelt" was established as a band of permanently protected territory in the Golden Horseshoe that maintains agriculture as the predominant land use and guards the agricultural land base from development [29-32]. These regulations, unfortunately have some negative consequences including increasing commuting distances [33], but also restricting the growth of the otherwise overwhelmingly environmentally-beneficial solar PV deployment. In the past, the reasons against PV on farm land were clear. The Ontario Federation of Agriculture stated: “...large scale solar on good farmland is not suited to Ontario. OFA believes solar development will cause erosion, bake the soil, disrupt carbon and nitrogen fixing, create habitat for weeds, and destroy habitat for many native creatures that share farmland. Large scale solar on good farmland will not produce any more power than if it were located on rooftops or rocks and it will reduce farm production needlessly. OFA policy is to protect good farmland rather than using it for solar." [34]. Historically, this position made sense as converting an active farm to a close-packed industrial-scale solar PV system would be expected to decrease agricultural production to zero.

A growing number of studies, however, indicate that it is possible to have large scale PV development while protecting agricultural production using the new innovation of agrivoltaics-- the strategic co-development of land for both PV electrical generation and agriculture [35-41]. Agrivoltaics provides several services illustrated in Figure 1.
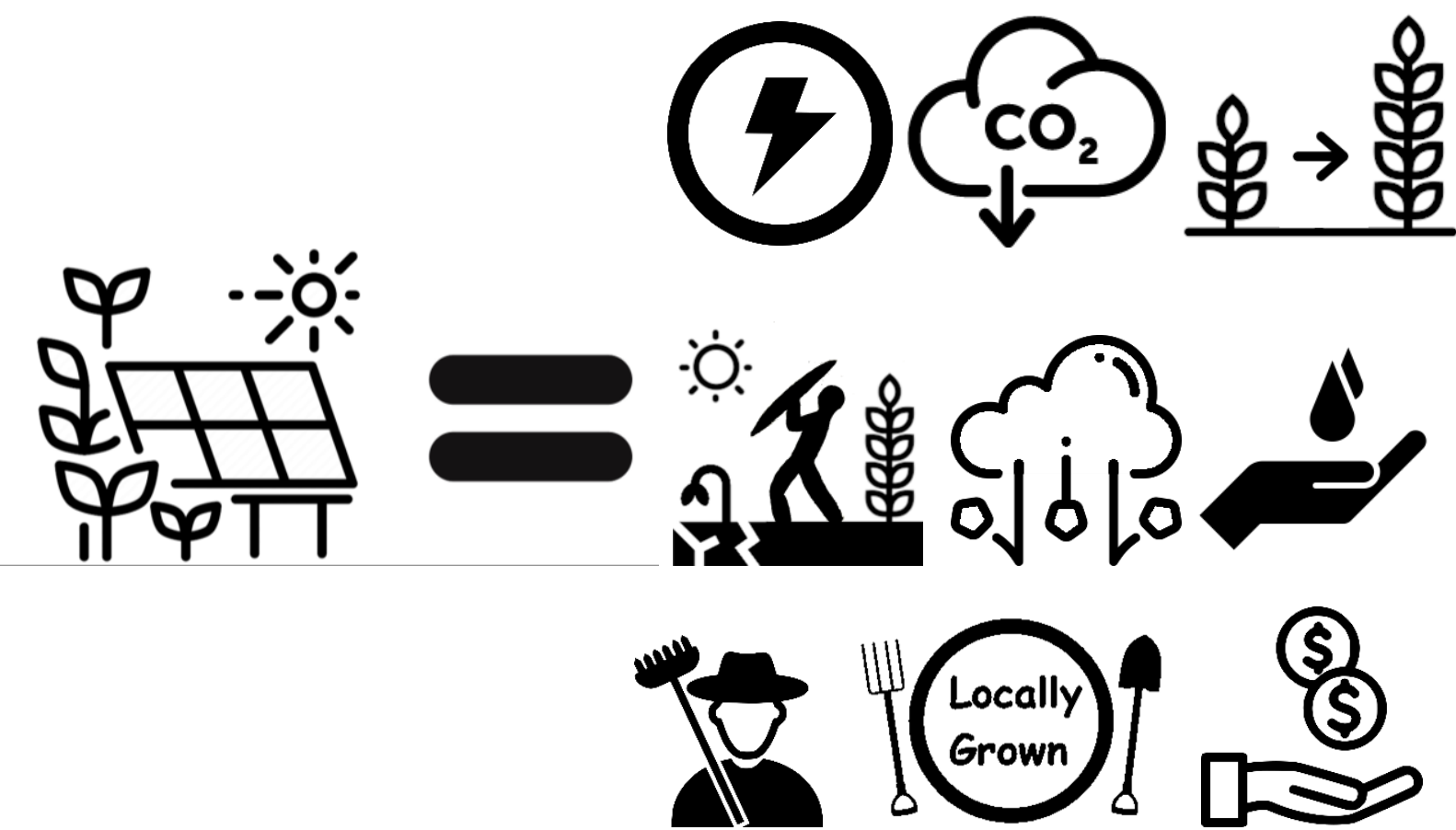

Figure 1. Services provided by agrivoltaics are a) renewable electricity generation, $b$, decreased greenhouse gas emissions, c) increased crop yeild, d) plant protection from excess solar energy, e) plant protection from incliment weather like hail, f) water conservation, g) agricultural employment, h) local food and i) increased revenue.

The first two outputs for agrivoltaics are well established as PV systems produce renewable electricity and this solar-generated electricity also decreases greenhouse gas (GHG) emissions when it offsets fossil fuel-based electricity production [42]. Agrivoltaics 
also ensures that land remains productive during the winter by generating electricity year-round. Less intuitively, many studies show that agrivoltaics increases crop yield for a variety of crops [43-47]. Increased crop yield and the PV electrical production substantially increase land use efficiency [48]. This is possible because agrivoltaics creates a microclimate beneath the PV modules that alters air temperature, relative humidity, wind speed, wind direction, and soil moisture [49]. Agrivoltaics protects crops from both excess solar energy and inclement weather like hail, while also improving PV performance because of lower operating temperatures $[35,45,50]$. Thus, agrivoltaics have the potential to actually increase global land productivity by $35-73 \%$ [51] rather than decrease it, while minimizing agricultural displacement for energy [36,52]. Agrivoltaics also offers more efficient use of water that provides for water conservation [53-56]. By maintaining the land for use in agriculture, employment of farmers remains intact and these farmers provide local sources of food along with all of the concomitant benefits [57-59]. Altogether, both the solar energy and the increased land use efficiency is worth money and thus increases revenue for a given acre for the farmer, the local community also benefits from protecting access to fresh food and renewable energy [37]. It should also be mentioned that advanced inverter management can also provide stability [60] to rural electric grids that can improve power quality [61-63] and if storage is implemented create emergency islanded power grids that can reduce outage impacts $[64,65]$.

Unfortunately, Canada is not yet on the forefront of agrivoltaics. There have been some notable demonstrations such as Arnprior's tri-part agrivoltaic system that houses a monarch butterfly conservation project, a bee/ honey project and a solar grazing/natural weed abatement pilot project [66]. Most Canadian agrivoltaics are primarily using conventional solar farms for grazing sheep, which does have positive benefits for both the sheep (i.e. protection [67] and higher quality grazing areas [68]), but also the PV systems (i.e. less labor for mowing) and the environment [69]. These lower-tier uses of agrivoltaics, however, leave out the majority of the potential agrivoltaic benefits. Other countries that make more aggressive use of agrivoltaics will generate more revenue per acre and win competitive markets.

As Canada in general, and Ontario in particular, is at a strategic disadvantage in the agricultural space without the use of agrivoltaics, this study investigates the policy changes necessary to capitalize on the benefits of using agrivoltaics in Ontario. First, the background on land use policy in Ontario will be reviewed in the context of renewable energy policy. Second, three short case studies of current Ontario crops: peppers, sweet corn and winter wheat, will be analyzed for the potential agrivoltaic boost to both crop production and solar energy generation. Third, these results will be discussed in conjunction with potential policies that would continue to protect the greenbelt of the Golden Horseshoe, while enabling and encouraging agrivoltaics in Ontario.

\section{Methods}

In section 3, the background on Ontario's land use policy will be reviewed in the context of renewable energy policy. After comparing the peer-reviewed literature for experimental agrivoltaic research of crops that showed an increase in yield with the list of crops in Ontario [70], three crops were selected. These crops were selected to have a variety of traditional shade tolerances as well as covering both vegetables and grains. First, peppers prefer direct sunlight in general, but pepper plants may still be grown in partial shade. This was shown to be beneficial with agrivoltaics as several varieties of peppers have shown an increase in yield under PV in a U.S. study [45]. Next, corn was selected as a crop that generally prefers full sun, and a recent study in Japan found increased sweet corn yields with agrivoltaics [47]. Finally, winter wheat was selected as a grain crop, and a German team recently showed increased yields with agrivoltaics [48]. The analysis is run under the assumption that all of the agricultural land currently dedicated to each crop is converted to an agrivoltaic system growing the same crop in the same area.

The potential estimated additional $(A)$ crop yield of each type in Ontario by:

$$
A_{c}=P_{c} y_{c} \quad[\mathrm{lbs}]
$$


where $P_{c}$ is the market production in Ontario [70] in lbs and $y$ is the yield increase in percent from experimental measurements in the literature $[45,47,48]$, and the $c$ subscript is for the crops of peppers, sweet corn and winter wheat, respectively. The value (V) of these crops is given by:

$$
V_{c}=A_{c} m_{c}
$$

where $m$ is the market value of the crop in Canadian dollars, which was determined by [70,71] and a sensitivity on the market value of wheat [72], respectively.

The potential solar power (S) for converting these crop areas over to agrivoltaics is given by:

$$
S_{c}=a_{c} y \quad[\mathrm{~kW}]
$$

where the area under cultivation (a) measured in acres is provided by the Ontario Ministry of Agriculture, Food and Rural Affairs [70,71] and the PV systems are modeled in two cases. The first, is the high packing factor case is conservatively assumed to be $314 \mathrm{~kW} /$ acre following Lytle et al. [73] in the U.S., but using partially transparent modules and closer packing. The second case is the low-packing factor case of $228 \mathrm{~kW} /$ acre for following Trommsdorff et al. [48], which was experimentally verified on high-mounted sparsely populated racks for the wheat case in Germany. Finally, the energy yield for PV systems of $S$ for each crop's agrivoltaic system is simulated in SAM [74] using the basic PVWatts model assuming fixed tilt at 30 degrees (high packing factor case) and 20 degrees (low packing factor case), facing due south and the solar flux for Orangeville, ON. The DC to AC size ratio was 1.2, inverter efficiency $96 \%$, a total loss of $13.2 \%$ comprised of $2 \%$ soiling losses, $3 \%$ snow losses, mismatch and wiring losses of $2 \%$ each, connections of $0.5 \%$ and light induced degradation of $0.5 \%$ and availability of $3 \%$. Finally, a sensitivity is applied the output solar energy $(\mathrm{kWh})$ by the cost of electricity, which was again conservatively estimated as the low $(\$ 0.0037 / \mathrm{kWh})$ and high $(\$ 0.0271 / \mathrm{kWh})$ monthly wholesale electricity prices reported by the IESO [75].

\section{Background on Ontario Land Use Policy}

\subsection{Governance}

Canada's national government operates as a federal democracy as well as a constitutional monarchy. Each subnational unit of government (i.e. provinces and territories) have a distinct legislature that oversees local matters and controls municipalities within its jurisdiction. Within the province of Ontario, municipalities are subject to a style of legislation known as "laundry list", in which the powers that are not explicitly stated or implied by the provincial legislature are not granted [76]. This is relatively restrictive. In the context of renewable energy development and agricultural land use, Ontario has made clear the rights of its municipalities through several policy documents, described below.

\subsection{Agricultural Heritage}

Ontario is in the heart of the Great Lakes region and possesses the most productive farmland in the country within the semicircle of area surrounding Lake Ontario. This area, known as the Greater Golden Horseshoe (GGH) [77], is shown highlighted in Figure 2. Fertile soils, abundant water resources, and a temperate climate coalesce to position the GGH as a leader in diverse and bountiful agricultural production. Within the GGH, the "Greenbelt" has been established as a band of permanently protected territory that maintains agriculture as the predominant land use and guards the agricultural land base from development. To uphold the agricultural legacy and the viability of the agri-food sector in Ontario, the province has developed a set of some of the most protective land use policies in the world. 


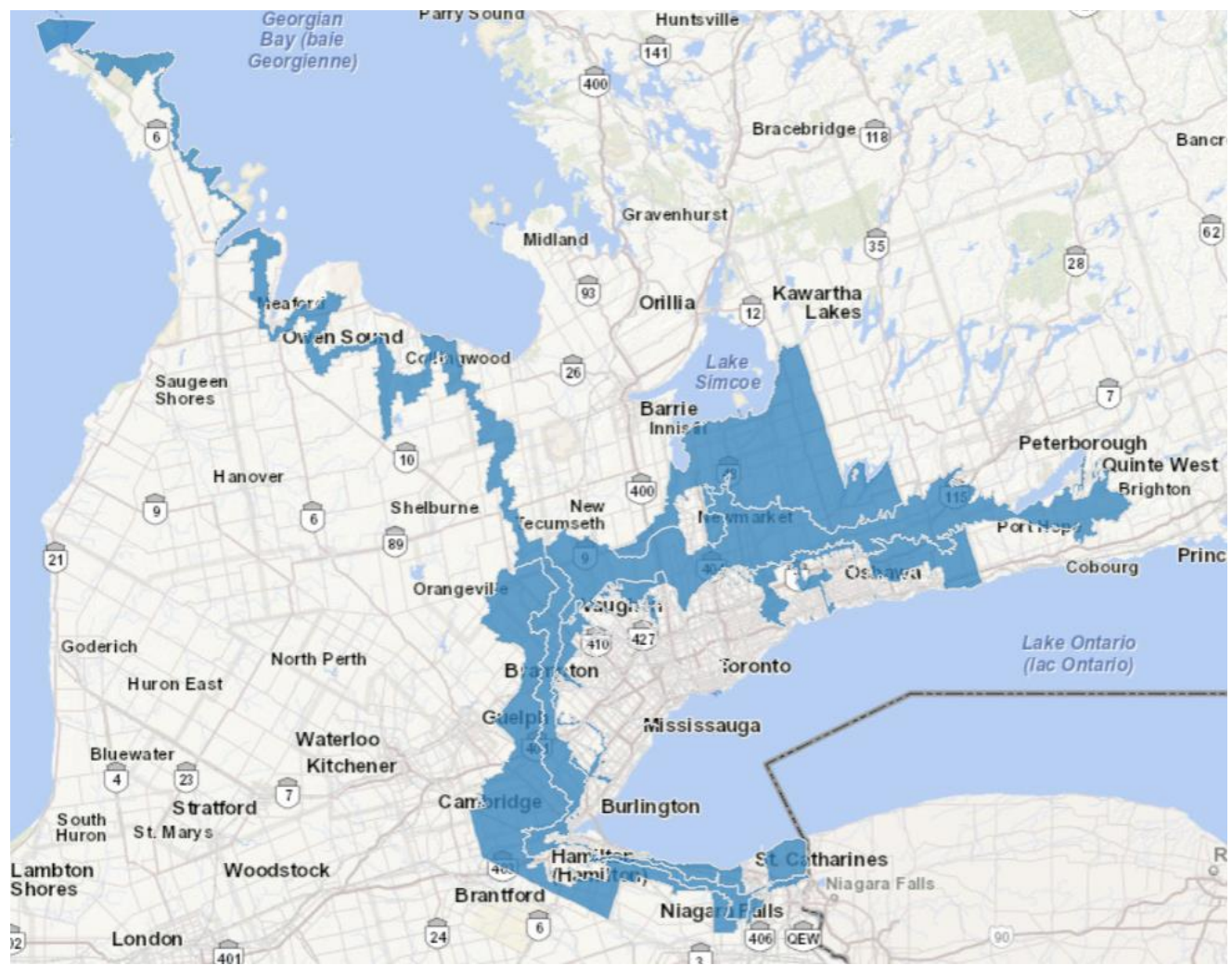

Figure 2. Land classified as green belt in Ontario [77].

\subsection{Land Use Policy in the Greenbelt}

The Provincial Policy Statement (PPS) (2020) lays the policy foundation for regulating the use and development of land in Ontario [78]. All subsequent ecological protection plans are built upon the PPS, including the Growth Plan for the GGH (2020) and the Greenbelt Plan (2017), which together form a provincial level fortress that protects agricultural land from development that may threaten continued use of the land for farming $[79,80]$. Municipal governments are tasked with further refining these sets of policies by generating place-based land designations, including prime agricultural areas and specialty crop areas in an "Official Plan." These plans must contain related criteria for permitted uses in these designated areas; the municipal level is thus the critical leverage point for agrivoltaic development.

\subsection{Renewable Energy Policy}

Being the first province in Canada to implement the feed-in tariff model through the Green Energy Act (2009), Ontario is the leader in solar energy in Canada [81]. Despite this leadership role within Canada, solar electricity still makes up less than $1 \%$ of electricity generation as shown in Figure 3. Part of this lack of PV capacity is that although provincewide criteria are imposed as minimum standards upon solar developments, these are followed by municipal level standards that are often more stringent and place-based. 


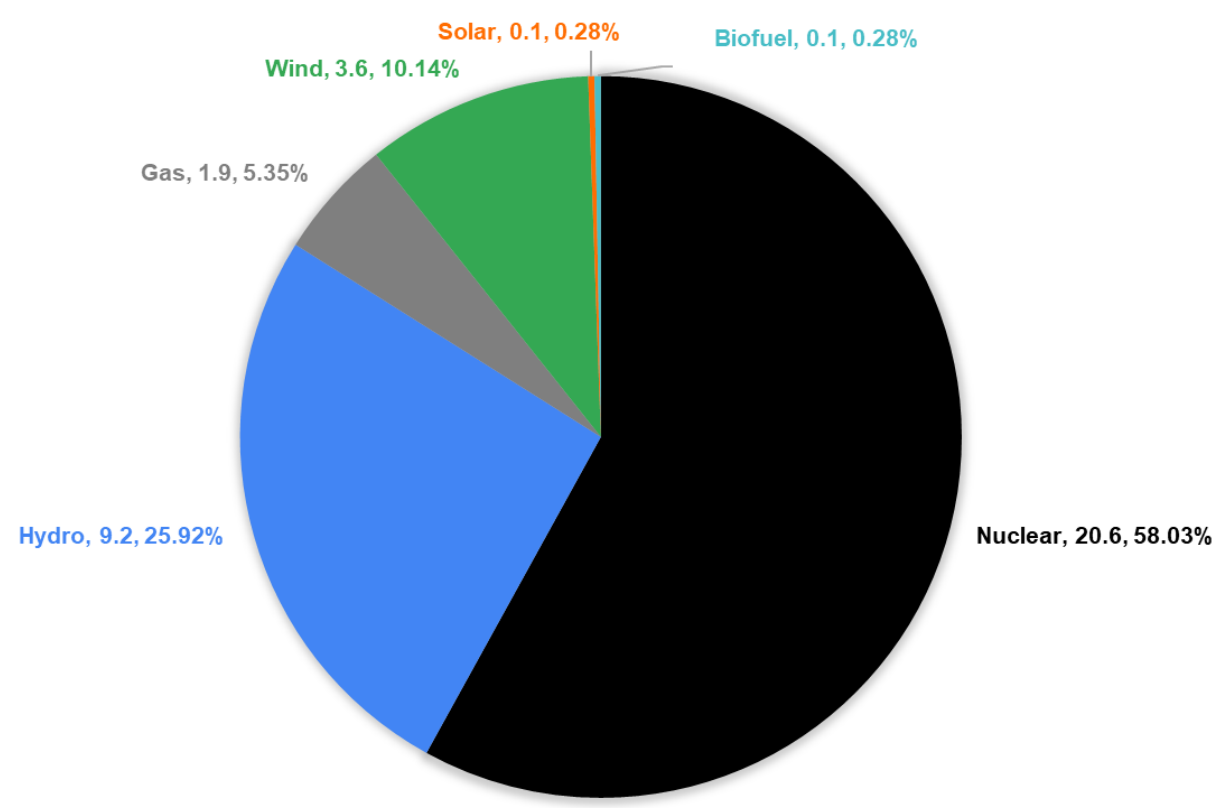

Figure 3. Electricity mix in Ontario [82].

\subsection{The Intersection of Agriculture and Solar Energy in Ontario}

Ontario's three-tiered land use policies defines what types of uses are allowed on prime agricultural lands, specialty crop areas, and rural areas. A full range of uses are permitted - particularly uses that increase income, diversify the tax base, and create employment opportunity - if specific criteria are met. Uses on these designated lands are organized under three categories: 1) agricultural, 2) agricultural-related, and 3) on-farm diversified [83].

Any proposed infrastructure that intersects these designated lands is subject to an agricultural impact assessment [84]. Renewable energy facilities are subject to the Green Energy Act (2009), rather than the Planning Act (1990), and therefore obtain approval under the REA rather than the PPS [83], while adhering to municipal land use criteria. For solar photovoltaics, these rules are particularly restrictive currently as the Provincial Policy Statement of 2020 states "Ground-mounted solar facilities are permitted in prime agricultural areas and specialty crop areas only as on-farm diversified uses." [85]. The intention of an "on-farm diversified use" is to diversify income for farmers through a secondary, compatible, limited use of the land. To qualify as on-farm diversified use in designated agricultural land, all uses (including a ground-mounted solar PV) must meet the following condensed list of key criteria [83]:

- Is related to, and is able to coexist with, agricultural operation

- Must not impair, inconvenience, or undermine surrounding agricultural operation

- Be located on a farm actively in production and be limited in area based on a lot coverage ratio basis (emphasis added)

- Meet all applicable provincial air emission, noise, water, and wastewater standards and receive all relevant environmental approvals

- Be secondary to the principal use of the property (agriculture), which is measured in spatial and temporal terms (the following temporal considerations apply to uses that are temporary):

- Does not require site grading and/or drainage unless it improves conditions for agricultural production

- Impacts to the site and agricultural operations are mitigated (e.g., compaction, drainage, trespassing)

- A harvestable crop is produced on the land the year in which the temporary use is implemented

This is heavily restrictive to PV farms without considering agrivoltaics. 


\section{Results and Discussion}

Assuming that all of the field crops were converted to agrivoltaic systems in Ontario for peppers, sweet corn and winter wheat, considerable amounts of food and additional revenue would be created as shown in Table 1.

Peppers would see the largest potential yield gain, which is worth $\$ 52$ million annually. This value must be used with caution as the calculation is extrapolated from substantial gains observed for agrivoltaics growing chiltepin peppers in Arizona (native to the U.S.). As agrivoltaics water conservation and excess solar shielding properties are robust, these may have been particularly useful in Arizona to increase yield peppers, whereas in Ontario this may or may not be the case. Other peppers could have different gains and the gains would be expected to vary with weather conditions and location just as is normally observed with agriculture. An additional $\$ 1.5$ million of sweet corn could be produced from the approximate $4.7 \%$ yield increase observed in Japan if agrivoltaics were used on Ontario's sweet corn crop. Finally, Ontario's winter wheat crop may produce between $\$ 9.6$ million and $\$ 22.8$ million in value if the same increase in crop yields are found as those reported in Germany. The value of agrivoltaic crop production increases are highly volatile because the cost of food commodities is highly volatile. This is best illustrated with the winter wheat case study as wheat prices are highly unstable as shown in Figure 4. Agrivoltaics provides farmers with a steady predictable revenue stream from electricity that helps dampen the risk of such volatility.

In summary, the specific economic values shown in Table 1 must be considered to only be illustrative estimates as they are derived from agrivoltaic yields compared to control crops in countries outside of Canada. In addition, the volatility in food crop prices is larger in percent than the percent increases generally expected for agrivoltaics. Even with these limitations in mind, it is clear from the results in Table 1, if only considering the agricultural services of agrivoltaics to increase yield it is an extremely promising opportunity for Ontario.

Table 1. Estimated additional yeild and crop values for agrivoltic enhanced crop potential in Ontario for peppers, sweet corn and winter wheat.

\begin{tabular}{lcccc} 
Crop & $\begin{array}{c}\text { Marketed } \\
\text { Production } \\
(\text { '000 lbs) }\end{array}$ & $\begin{array}{c}\text { Average } \\
\text { Price } \\
(\mathbf{c e n t s} / \mathbf{l b})\end{array}$ & $\begin{array}{c}\text { Additional } \\
\text { yield } \\
(\mathbf{\prime} 000 \mathrm{lbs})\end{array}$ & $\begin{array}{c}\text { Additional } \\
\text { Agrivoltiac } \\
\text { Crop Value }\end{array}$ \\
\hline Peppers & 87,960 & 33.7 & 154,810 & $\$ 52,170,835$ \\
\hline Sweet Corn & 216,958 & 15.4 & 10,150 & $\$ 1,563,113$ \\
\hline $\begin{array}{l}\text { Winter Wheat } \\
\text { (low value) }\end{array}$ & $4,818,000$ & 6.7 & 144,540 & $\$ 9,684,180$ \\
\hline $\begin{array}{l}\text { Winter Wheat } \\
\text { (high value) }\end{array}$ & $4,818,000$ & 15.8 & 144,540 & $\$ 22,837,320$
\end{tabular}




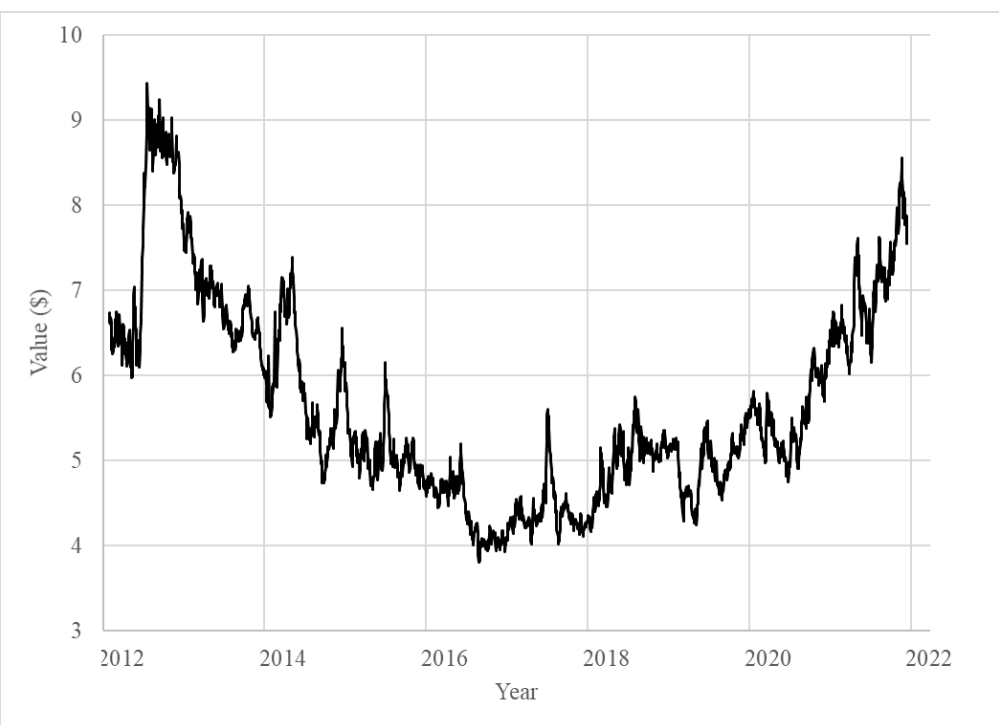

Figure 4. Volatile wheat prices $(\$ / b u)$ over the last decade.

The potential value from the solar electricity generated from the conversion of field crops in Ontario for peppers, sweet corn and wheat also has a considerable variance. This variance is caused by two fundamental variables: 1) the packing factor measured in $\mathrm{kW} / \mathrm{acre}$ for the PV modules and 2) the value of the generated electricity. The former is a complicated geometric combination of both the light transmission value of the PV modules (agrivoltaic modules can be monofacial, bifacial and partially transparent for both modalities, which all have an impact on the power of a module) as well as the array geometry and spacing between both rows and modules within a row. To investigate the sensitivity of the packing factor two cases are considered the first at $314 \mathrm{~kW} /$ acre would be viewed as a reasonable value for a conventional agrivoltaic system while the value of $228 \mathrm{~kW} / \mathrm{acre}$ is what has been experimentally tested for large area grain-based agrivoltaic production. This large variance is seen in the results for the high and low packing factor agrivoltaic cases of additional PV-generated electricity for Ontario per year shown in Tables 2 and 3, respectively. The corn and wheat are probably closer to the optimum performance for the crop using the lower values in Figure 3, which indicates if all of Ontario's farm land currently growing sweet corn and winter wheat were converted to agrivoltaics additional electricity revenue (most likely coming from sales of wholesale electricity to the U.S.) would account for $\$ 1.02$ and $\$ 7.48$ billion/year in revenue. In the case of the peppers the packing factor shown in Table 2 is likely more appropriate providing between $\$ 5.8$ and $\$ 42.7$ million in additional solar electric revenue per year from the fields currently growing peppers in Ontario. By comparing the value of the additional crop revenue (Table 1) and the solar electric revenue (Table 2 and 3) it is not surprising that the latter is much higher because the values in Table 1 are only the increases not the overall revenue from crop farming the same area.

As can be seen in both Table 2 and 3, the value of electricity covers a wide range even when considering only using the extremely conservative average monthly wholesale rates for the electricity values. Retail rates of electricity can increase the value of even the high rate used in the Tables by a factor of ten and on-peak rates (generally during the summer when caused by high temperatures and widespread air conditioner use when PV production is highest) are much higher than that. The results presented in Table 2 and 3 are thus illustrative of the rough minimum value of the solar electricity that would be generated by the agrivoltaic systems. Determining the exact value of the electricity potentially generated from such agrivoltaic systems is far beyond the scope of this study as it would entail not only geographic considerations for the technical aspects (e.g. horizon shading and latitude changes throughout Ontario), but also economic ones that would vary with for example the year, the penetration rate of solar, the value of offsetting GHG 
emissions, etc. Overall the value of solar (VOS) is a complex topic [86], which needs to be calculated for each specific case and is left for future work. In addition, the values shown here also do not include the second order effects (e.g. agrivoltaic systems operate cooler than conventional solar farms, which provides about a $1 \%$ increase in PV output annually). Overall, it is clear that the combination of the values in Table 1 with either those in Table 2 or 3 are a promising source of additional revenue for farms in Ontario.

Table 2. High-packing factor agrivoltaic case of additional PV-generated electricity for Ontario per year.

\section{Additional}

\begin{tabular}{|c|c|c|c|c|c|}
\hline Crop & $\begin{array}{c}\text { Area Har- } \\
\text { vested } \\
\text { (acres) }\end{array}$ & $\begin{array}{c}\text { Additional PV } \\
\text { Power (kW) }\end{array}$ & $\begin{array}{c}\text { Energy } \\
\text { (kW- } \\
\text { hrs/year) }\end{array}$ & $\begin{array}{c}\text { Low value } \\
(\$ 0.0037 / \mathrm{kWh})\end{array}$ & $\begin{array}{c}\text { High value } \\
(\$ 0.0271 / \mathrm{kWh})\end{array}$ \\
\hline Peppers & 3,808 & $1,195,712$ & $1.58 \mathrm{E}+09$ & $\$ 5,835,433$ & $\$ 42,740,606$ \\
\hline Sweet Corn & 21,834 & $6,855,876$ & $9.04 \mathrm{E}+09$ & $\$ 33,458,732$ & $\$ 245,062,602$ \\
\hline Winter Wheat & 920,000 & $288,880,000$ & $3.81 \mathrm{E}+11$ & $\$ 1,409,821,064$ & $\$ 10,325,986,712$ \\
\hline
\end{tabular}

Table 3. Low-packing factor agrivoltaic case of additional PV-generated electricity for Ontario per year.

\section{Additional}

\begin{tabular}{|c|c|c|c|c|c|}
\hline Crop & $\begin{array}{c}\text { Area Har- } \\
\text { vested } \\
\text { (acres) }\end{array}$ & $\begin{array}{l}\text { Additional } \\
\text { PV (kW) }\end{array}$ & $\begin{array}{c}\text { Energy } \\
\text { (kW- } \\
\text { hrs/year) }\end{array}$ & $\begin{array}{c}\text { Low value } \\
(\$ 0.0037 / \mathrm{kWh})\end{array}$ & $\begin{array}{c}\text { High value } \\
(\$ 0.0271 / \mathrm{kWh})\end{array}$ \\
\hline Peppers & 3,808 & 868,224 & $1.12 \mathrm{E}+09$ & $\$ 4,131,183$ & $\$ 30,258,127$ \\
\hline Sweet Corn & 21,834 & $4,978,152$ & $6.40 \mathrm{E}+09$ & $\$ 23,687,043$ & $\$ 173,491,584$ \\
\hline Winter Wheat & 920,000 & $209,760,000$ & $2.70 \mathrm{E}+11$ & $\$ 998,080,032$ & $\$ 7,310,261,856$ \\
\hline
\end{tabular}

\section{Policy Recommendations}

Agrivoltaics should be considered an agricultural use or agricultural-related use due to its positive impact on agricultural production and solar PV electricity production. The light management that agrivoltaics provides (especially for greenhouse integrated photovoltaic (GiPV)[87]) that leads to yield increase should be consider equivalent to the use of crop rotation strategies or water and nutrient management practices.

Table 4 outlines Ontario's province-wide criteria [83] for use of prime agricultural lands, which are more acutely defined at the municipal level, and then considers agrivoltaic as well as conventional solar farm acceptability. As can be seen in Table 4, agrivoltaics meet these requirements while conventional PV farms do not.

Table 4. Conventional solar farm and agrivoltaics matches to criteria for permitted uses in prime agricultural areas in Ontario.

\section{Conven-}

tional

$\begin{array}{lll}\text { Criteria for permitted uses in prime agricultural areas } & \text { PV Farm } & \text { Agrivoltaics }\end{array}$

1. Farm-related commercial and farm-related industrial Yes

2. Shall be compatible with and shall not hinder surNo

Agriculture continues rounding agricultural operations Yes Benefits Agricultural Yes 
Yes

Yield increase, water conservation and 4. Supports agriculture No plant protection

Yes, if

some

5. Provides direct products and/or services to farm opera- power goes Yield increase, Must be considtions as a primary activity to farm ered holistically Yes

6. Benefits from being in close proximity to farm operaLower PV operating temperations No tures

A second path to adding PV infrastructure on agricultural land in Ontario is to utilize the rules for on-farm diversified criteria summarized in Table 5 for conventional PV farms as well as agrivoltaics. In this case, the interpretation enables some PV systems to be built, particularly if the area is limited. This limited area requirement does not appear to make sense in the agrivoltaic context. If agrivoltaics are improving the agricultural production of a farm as well as the economics and environmental impact, the area for which it is utilized should be maximized instead of restricting it?

Table 5. Conventional solar farm and agrivoltaics matches to criteria permitted for on-farm diversified uses in prime agricultural areas in Ontario.

\begin{tabular}{|c|c|c|}
\hline On-Farm Diversified & $\begin{array}{c}\text { Conventional } \\
\text { PV Farm }\end{array}$ & Agrivoltaics \\
\hline 1. Located on a farm & Yes & Yes \\
\hline $\begin{array}{l}\text { 2. Secondary to the principal agricultural } \\
\text { use of the property }\end{array}$ & Maybe & $\begin{array}{c}\text { Yes, } \\
\text { holistically }\end{array}$ \\
\hline 3. Limited in area & Unclear & Unclear \\
\hline $\begin{array}{l}\text { 4. Includes, but is not limited to, home oc- } \\
\text { cupations, home industries, agri-tourism } \\
\text { uses and uses that produce value-added ag- } \\
\text { ricultural products }\end{array}$ & 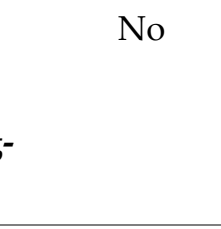 & Yes \\
\hline $\begin{array}{l}\text { 5. Shall be compatible with, and shall not } \\
\text { hinder, surrounding agricultural operations }\end{array}$ & Yes & Yes \\
\hline
\end{tabular}

Rather than outright bar the use of large-scale PV on farms, given the numerous benefits (Figure 1) to farmers including the potential to increase agricultural output, it would appear rational to consider encouraging agrivoltaics in Ontario and the rest of Canada. This is perhaps made even clearer by the fact that nearly all of the experimental agrivoltaic research is made outside of Canada in nations that will quickly have a competitive agricultural advantage if they deploy agrivoltaics at scale. As the results show in Tables 1-3, these advantages have real economic consequences that could leave Ontario's farmers uncompetitive without them.

While maintaining the land base for agriculture is paramount, another important objective of Ontario's land use policy is supporting the growth of the rural economy. Historically when energy development is proposed that offsets food production on agricultural 
land while also providing rural economic opportunity, a land use conflict arises between competing objectives. Agrivoltaic development solves this problem in general and can solve this issue in Ontario. There are four primary policy areas involving agrivoltaics in Ontario and Canada that need attention in order for this to occur: 1) research and development, 2) education/public awareness, 3) policy mechanisms to support farmers and 4) utilize agrivoltaics as a potential source of trade surplus with the U.S.

\subsection{Support Applied Agrivoltaic Research in Ontario}

First, the results of this analysis make it clear that agrivoltaic research in Ontario should be supported. This work should first concentrate on Ontario's major markets for agriculture. This not only includes the crops that have more than 10,000 acres devoted to them in Ontario (e.g. sweet corn with 21,834 acres used as a case study here, green peas with 15,507 acres, tomatoes with 15,223 acres and green/wax beans with 10,208 acres, but also the dozens of other vegetables and specialty crops [70]. In addition, agrivoltaic research should be performed to consider including the more than 2.1 million acres of grain corn and over 3 million acres of soybeans as well as other grains and dried beans [71].

Agrivoltaics is under intense research in other parts of the world, but to date only a handful of crops have been investigated including: aloe vera [88], aquaponics (aquavoltaics) [89], basil and spinach [90], celeriac [91], chiltepin peppers, jalapenos, cherry tomatoes [45], sweet corn/maize [47,92], grapes [93], kale, chard, broccoli, peppers, tomatoes, and spinach [46], lettuce [43,53], pasture grass [49], potato, celeriac, clover grass, winter wheat [48], and wheat [35,94]. In general, these studies showed either marginal impacts on crop production or an increase for low density shading from agrivoltaics. Increases were seen primarily with shade tolerant crops and leafy vegetables like lettuce that prefer partial shading from PV to prevent bolting and increasing growth time. Decreases, however, were observed for heavy shading from close-packed non-transparent PV.

To guide agrivoltaic design, Riaz et al. has introduced the light productivity factor, which can be used to start evaluating the effectiveness of irradiance sharing for specific crop types based on its effective photosynthetically active radiation (PAR) and PV array design [95]. Agrivoltaic research and optimization is far from complete. Most studies to date have focused on a single crop (or a few) and tested one basic geometry of the PV systems in one location. There is far more research needed as there are dozens of crops commercialized in Ontario and over 20,000 species of edible plants [96]. In addition, PV system designs can impact agrivoltaic production including the following variables:

(i) array geometry, orientation and type of racking [97],

(ii) fixed tilt, single axis or dual axis tracking,

(iii) type of module (size, monofacial vs bifacial, uniform like thin film modules or non-uniform transmission from silicon cell-based PV technology)

(iv) type of PV material that constitutes the module (e.g. single bandgap, bandgap value, or multiple bandgaps)

(v) transparency of module,

(vi) spectral transmission of module including the impact of optical enhancement techniques such as anti-reflection coatings (ARCs) (i.e. partially transparent colored PV are under investigation for windows $[98,99]$ that could also be useful for agrivoltaics. Already semi-transparent PV have been integrated into greenhouses [99-103] and tinted semi-transparent PV can actually yields for some plants [104]).

(vii) the use of spectral shifting materials within the module if the agrivoltaic system is in an open field or enclosed in a greenhouse. Such spectral shifting materials are being investigated for use in greenhouses to make the light more beneficial for plant growth [105-107] and increase greenhouse production [108].

The potential permutations need to be optimized for Ontario and its crops, which represents an enormous amount of experimentation. New agrivoltaic systems need to be tested and optimized for compatibility with target crops and their associated operations 
(e.g. soil management, fertilization, sowing, irrigation, and harvesting, as well as dust generation during these agricultural operations). For example, greenhouse solar panels [109] could be optimized for specific crops by altering the transparency by spacing of cells in a module. Doing this one commercial greenhouse $[110,111]$ at a time per crop would be both expensive and time consuming for even one given module. This, however, becomes completely prohibitive once module experimentation is also considered. For example, 'red greenhouse modules' themselves needed to be optimized for (e.g. testing the density, size and chemical makeup of nano-particles responsible for the spectral shifting via fluorescence [112-114]). They also needed tested both for field use as well as greenhouse use. Innovation is already happening in this are in Ontario [87]. Enabling agrivoltaics could drive additional local innovation development and job growth. Agrivoltaics would thus benefit from coordination and partnering between funders focused on energy (e.g. The Office of Energy Research and Development (OERD)) and agriculture (e.g. The Agricultural Research Institute of Ontario and the Ministry of Agriculture, Food and Rural Affairs in Ontario).

\subsection{Increase Public Awareness of Agrivoltaics in Ontario}

To overcome these challenges related to the vast quantity of research needed in agrivoltaics, a parametric open source cold-frame agrivoltaic systems (POSCAS) was proposed to make low-cost agrivoltaic testing systems work in one single-module mini greenhouse at a time [115]. These devices could be used at a research station to test many variables at once. More importantly, these devices could also be used to foster public awareness of agrivoltaics using the approach of citizen science [116,117]. By enabling citizens to investigate the large number of permutations of PV designs and crops, two problems will be solved simultaneously. Such an enterprise could first, for example, target the help of master gardeners to quickly screen local produce for benefits for agrivoltaics by providing them with a free POSCAS and open source collaborative well-structured online research reporting. This would minimize $R \& D$ costs while also educating the wide population about the benefits of agrivoltaics.

Most North Americans are simply unaware of agrivoltaics, but when exposed to the idea they are in support of it [118]. Citizen science, like that described above may help in part with public awareness, but broad openly-accessible demonstrations are needed to verify the viability of the agrivoltaic approach in Ontario and to inform policymakers as well as build public trust. After preliminary experimental Ontario-based agrivoltaic studies indicate promise, open pilot studies should be conducted to allow farmers and citizens free access to the results. Opening rural lands to agrivoltaic R\&D and demonstration can also prevent other types of proposed development on prime agricultural lands, while ramping up education on agrivoltaics in the province.

\subsection{Streamline Agrivoltaic System Deployment and Regulation}

Given the modest agrivoltaic presence in Canada currently, in addition to more R\&D and public education, there exists a need for an explicit definition and classification of agrivoltaic systems for regulation purposes. Agrivoltaics transcend traditional photovoltaic development by allowing continued use of the farmland beneath the array, and is therefore uniquely positioned to enable the prosperity of agricultural producers and the diversification of their income, while stimulating rural economic growth through the generation of low-carbon electricity from sunlight. A proper definition is needed to acknowledge that agrivoltaics will not disrupt the geographic continuity of the agricultural land base. In order to prevent abuse of agrivoltaic-friendly regulations it may be useful to divide agrivoltaics up into tiers as is shown in Table 6. Tier 1 agrivoltaic solutions would be preferred and incentivized over Tier 2, etc. Such a tiered system, would for example prevent a solar developer from simply seeding a conventional PV farm with wildflowers to acquire access to prime agricultural land.

Ontario can look to other jurisdictions such Japan, the U.S. and Europe for examples of effective agrivoltaic policy. In Japan, agrivoltaic development exploded after the 
introduction of feed-in tariff (FIT) in 2012 [119]. Tajima and Iida, found that the FIT was significantly more effective than a renewable portfolio standard (RPS) system previously used in Japan and that agrivoltaics is expected play a major role to revitalize the Japanese agriculture including reclamation of abandoned farmland [119]. Whereas in the Massachusetts, their Department of Energy Resources established the Solar Massachusetts Renewable Target (SMART) program that regulates and provides incentives for PV and agrivoltaics in particular [120-122]. In Europe, a standard has been developed as a test method for agrivoltaic systems that provides a uniform way to report agrivoltaic measurement figures for legislative and funding bodies and the approval authorities, as well as for the post-testing and certification of agrivoltaic systems by experts and certification organizations [123]. Canada could build upon and improve upon these standards and ensure they remain open access and thus freely available to all of Ontario's farmers.

Table 6. Potential tiers of agrivoltaic systems to favor systems with greater landuse efficiency and greater potential for GHG emissions reductions.

\begin{tabular}{lcc}
\hline $\begin{array}{l}\text { Tier/ Allowed } \\
\text { Land Use }\end{array}$ & Agrivoltaic Type & Comments \\
\hline 1. Prime agriculture & Crop & $\begin{array}{c}\text { See Section 5.1 for crops } \\
\text { investigated to date }\end{array}$ \\
\hline 2. Pasture & Grazing & $\begin{array}{c}\text { Sheep [51,124], and rab- } \\
\text { bits [73] }\end{array}$ \\
\hline 3. Marginal & Apiculture & $\begin{array}{c}\text { Honey production [125] } \\
\text { (beekeeping) }\end{array}$ \\
\hline 4. Non-restricted & Insect Habitat & $\begin{array}{c}\text { Pollinators like butter- } \\
\text { flies that provide sec- } \\
\text { ondary services }\end{array}$ \\
\hline
\end{tabular}

Thus, a legal recognition of agrivoltaics as an agriculture-related use, or an on-farm diversified use (see Tables 4 and 5), by the province of Ontario and the relevant municipal permitting systems could help overcome the current barriers to PV development embedded in the regulatory process. Authorizing agrivoltaics on prime agricultural land through either of these land use classifications will generate a distinct development opportunity for Ontario. Thus, agrivoltaic growth will be directed to uphold the economic, social, and environmental aims of the province's land use policies without compromising the quality of agricultural land for future generations.

Finally, to increase agrivoltaic deployment velocity in Ontario, provincial and municipal policies should be aligned. Policy related to energy development and agricultural land use in Ontario at both the provincial and municipal level are robust, yet the regimes are stratified and siloed, which also complicates the realization of agrivoltaic systems. To minimize incompatibility between renewable energy and farmland preservation goals, provisions are needed that clearly address the overlap between the siting of energy systems on farmland which maintain the existing land use (i.e., agrivoltaics). The current policy language does not account for solar PV systems that retain the agricultural function of the land; this omission, while likely unintended (as agrivoltaics is a relatively new field), stops the potential for dual-use system development. Finally, provincial energy policy could incentivize agrivoltaics, followed by special municipal-level criteria for the siting and design of systems. Aligning energy policy regimes with place-based land use regulations would create a supportive policy landscape for the development of agrivoltaics in Ontario. 
Although Ontario will need to develop new generation capacity to displace the loss of nuclear generation when Pickering nuclear generation station (15\% of Ontario's total) retires in 2024 and growth from electric vehicles and heating electrification growth, Ontario, itself is already fairly advanced in terms of low-carbon electricity generation and has closed its coal plants. As can be seen in Figure 3, very little of Ontario's current electricity production is a large source of GHG emissions, however, international power lines currently connect Canada to the U.S. Ontario has interconnections with Manitoba and Quebec in Canada and Michigan, Minnesota, and New York in the U.S. This provides Ontario, the opportunity to offset emissions with low carbon power from agrivoltaics in the Eastern U.S. (Maine, New Hampshire, Vermont, New York, and Massachusetts), the U.S. West (Washington and Montana), and the U.S. Midwest (North Dakota, Minnesota, and Michigan). The U.S. interest in Ontario's electricity stems in part from renewable portfolio standards (RPS) and renewable electricity targets in many U.S. states, which mandate minimum levels of renewable power in each state's electricity mix and often do not distinguish between domestic and imported renewable power. As many U.S. states have abysmal carbon emissions [126], Ontario's exports of renewable solar power to the U.S. is well positioned to grow [127].

This is because as of 2018, about $96 \%$ of electricity generated in Ontario was produced from zero-carbon emitting sources [128]. The U.S. is less fortunate, with over half of its electricity produced by coal-fired power plants that are directly responsible for more than 50,000 premature American deaths per year from the coal-fired power plant related air pollution [130]. Agrivoltaics in Ontario has the promise to reduce this American coal-fired pollution related death toll at a provincial profit It should also be noted that American coal-fired air pollution unquestionably invades Canada from the southern border and causes premature Canadian death and medical costs as well, but as of yet has not been adequately quantified. Agrivoltaics in Ontario could end these negative impacts on Canadians economy and livelihoods while earning U.S. funds. For example, if experimental results in Ontario's grain corn acreage was to have similar results to that of Japan's sweet corn acreage and is converted to agrivoltaics, this would provide area to install over 478 GW of PV, which would be expected to produce roughly 6.16E+11 kWhrs/year (616 TWhrs/year). To put this in perspective, this is an order of magnitude higher than Ontario's current capacity and could offset $16.8 \%$ of all of the U.S.'s electrical consumption [126]. This result is consistent with previous work that found constructing agrivoltaics on less than $1 \%$ of the world's cropland is enough to generate electricity for the entire planet [52]. Similarly, PV power of 40-70 GW would be possible if lettuce cultivation alone were converted to agrivoltaic systems in the U.S. [37], but the U.S. faces a politically fractured policy landscape. Thus, for Ontario to take advantage of this opportunity it needs to move more quickly at modernizing land use regulations before the policy-fractured U.S. While this is the theoretical potential increase Ontario's solar PV capacity, additional large-scale transmission development to deliver excess energy to the U.S. is required, which will have a land use impact. Future research is needed to quantify the technical requirements, costs and ROI of this approach as well as expand them to all the potential crops across Canada $[131,132]$.

\section{Conclusions}

The results of this study make it clear that four agrivoltaic policy areas need further attention: 1) research and development, 2) education/public awareness, 3) mechanisms to support Ontario's and Canada's farmers converting to agrivoltaics and 4) using agrivoltaics as a potential source of trade surplus with the U.S. It is concluded that consideration should be given to the development of agrivoltaics in Ontario, by first warranting agricultural research opportunities throughout the province (Section 5.1), followed by siting criteria designed specifically for these systems to allow for rapid deployment for demonstration systems for the public (Section 5.2). The findings of this study suggest that policy changes (Section 5.3) are needed to increase the deployment of agrivoltaics in Ontario, including: i) dual-use agrivoltaic systems should have a legally recognized definition, ii) 
provincial energy regimes and municipal land use regulations should be aligned to overcome incompatibility of policies, iii) agrivoltaics should be expressly permitted for deployment in various regions after pilot studies provide verification of technical viability, and iv) agrivoltaics should be appropriately incentivized through policy mechanisms to encourage maximized sustainable land use. By amending land use policies and using incentives to support agrivoltaics, the province of Ontario can ensure the preservation of farmland and growth of the agri-food sector while advancing their aggressive renewable energy, economic and climate-related goals.

Funding: This research was supported by the Thompson Endowment.

Data Availability Statement: Data is available upon request.

Acknowledgments: This article benefited from helpful comments from R. Sinclair, M. Pochtaruk and A. Pascaris.

Conflicts of Interest: The author declares no conflict of interest.

\section{References}

1. Feldman, D.; Barbose, G.; Margolis, R.; Wiser, R.; Darghouth, N.; Goodrich, A. Photovoltaic (PV) Pricing Trends: Historical, Recent, and Near-Term Projections; National Renewable Energy Laboratory: Golden, CO, USA, 2012.

2. Barbose, G.L.; Darghouth, N.R.; Millstein, D.; LaCommare, K.H.; DiSanti, N.; Widiss, R. Tracking the Sun X: The Installed Price of Residential and Non-Residential Photovoltaic Systems in the United States; Lawrence Berkley National Laboratory: Berkeley, CA, USA, 2017.

3. IRENA. Renewable Power Generation Costs in 2017; IRENA: Abu Dhabi, United Arab Emirates, 2018.

4. Dudley, D. Renewable Energy Will Be Consistently Cheaper than Fossil Fuels By 2020, Report Claims. Forbes 2018. Available online: https://www.forbes.com/sites/dominicdudley/2018/01/13/renewable-energy-cost-effective-fossilfuels-2020/ (accessed on 7 April 2020).

5. Baldus-Jeursen, C. National Survey Report of PV Power Applications in Canada. 34. https://iea-pvps.org/wpcontent/uploads/2021/03/NSR Canada 2019.pdf

6. Pearce, J.M.; Sommerfeldt, N. Economics of Grid-Tied Solar Photovoltaic Systems Coupled to Heat Pumps: The Case of Northern Climates of the U.S. and Canada. Energies 2021, 14, 834. https://doi.org/10.3390/en14040834

7. Pearce, J.M. Photovoltaics--a Path to Sustainable Futures. Futures 2002, 34, 663-674.

8. Pearce, J.; Lau, A. Net Energy Analysis For Sustainable Energy Production From Silicon Based Solar Cells. In Proceedings of the American Society of Mechanical Engineers Solar 2002: Sunrise on the Reliable Energy Economy, Reno, NV, USA, 15-20 June 2002.

9. NREL. Best Research-Cell Efficiency Chart. Available online: https://www.nrel.gov/pv/cell-efficiency.html (accessed on 12 January 2021).

10. Bhandari, K.P.; Collier, J.M.; Ellingson, R.J.; Apul, D.S. Energy payback time (EPBT) and energy return on energy invested (EROI) of solar photovoltaic systems: A systematic review and meta-analysis. Renew. Sustain. Energy Rev. 2015, 47, 133-141.

11. Denholm, P.; Margolis, R.M. Land-use requirements and the per-capita solar footprint for photovoltaic generation in the United States. Energy Policy 2008, 36, 3531-3543.

12. Engelke, P. Foreign Policy for an Urban World: Global Governance and the Rise of Cities; Atlantic Council (Washington DC, USA): 2013.

13. What Percentage of Canadians Live in Cities and Towns? Available online: http://www.canadafaq.ca/what+percentage+canadians+live+in+cities/ (accessed on 18 December 2021).

14. Wüstenhagen, R.; Wolsink, M.; Bürer, M.J. Social acceptance of renewable energy innovation: An introduction to the concept. Energy Policy 2007, 35, 2683-2691, doi:10.1016/j.enpol.2006.12.001.

15. Sovacool, B. Exploring and Contextualizing Public Opposition to Renewable Electricity in the United States. Sustainability 2009, 1, 702-721, doi:10.3390/su1030702.

16. Sovacool, B.K.; Ratan, P.L. Conceptualizing the acceptance of wind and solar electricity. Renew. Sustain. Energy Rev. 2012, 16, 5268-5279.

17. Batel, S.; Devine-Wright, P.; Tangeland, T. Social acceptance of low carbon energy and associated infrastructures: A critical discussion. Energy Policy 2013, 58, 1-5. 
18. Calvert, K.; Mabee, W. More solar farms or more bioenergy crops? Mapping and assessing potential land-use conflicts among renewable energy technologies in eastern Ontario, Canada. Appl. Geogr. 2015, 56, 209-221, doi:10.1016/j.apgeog.2014.11.028.

19. Calvert, K.; Pearce, J.M.; Mabee, W.E. Toward renewable energy geo-information infrastructures: Applications of GIScience and remote sensing that build institutional capacity. Renew. Sustain. Energy Rev. 2013, 18, 416-429, doi:10.1016/j.rser.2012.10.024.

20. Nonhebel, S. Renewable energy and food supply: Will there be enough land? Renew. Sustain. Energy Rev. 2005, 9 , 191-201, doi:10.1016/j.rser.2004.02.003.

21. Dias, L.; Gouveia, J.P.; Lourenço, P.; Seixas, J. Interplay between the Potential of Photovoltaic Systems and Agricultural Land Use. Land Use Policy 2019, 81, 725-735, doi:10.1016/j.landusepol.2018.11.036.

22. UN Department of Economic and Social Affairs. Concise Report on the World Population Situation in 2014; UN, NewYork, US: 2014.

23. FAO. How to Feed the World 2050. 2009. Retrieved 3 December 2020. Available online: http://www.fao.org/fileadmin/templates/wsfs/docs/Issues papers/HLEF2050 Global Agriculture.pdf (accessed on 25 Oct. 2021).

24. Runge, C.F.; Senauer, B. How Biofuels Could Starve the Poor. Foreign Aff. 2007, 86, 41.

25. Tomei, J.; Helliwell, R. Food versus Fuel? Going beyond Biofuels. Land Use Policy 2016, 56, 320-326, doi:10.1016/j.landusepol.2015.11.015.

26. Thompson, P.B. The Agricultural Ethics of Biofuels: The Food vs. Fuel Debate. Agriculture 2012, 2, 339-358. https://doi.org/10.3390/agriculture2040339

27. Tenenbaum, D.J. Food vs. Fuel: Diversion of Crops Could Cause More Hunger. Environ. Health Perspect. 2008, 116, A254-A257, doi:10.1289/ehp.116-a254.

28. Canada Population Rate 1950-2021 Available online: https://www.macrotrends.net/countries/CAN/canada/population-growth-rate (accessed on 19 December 2021).

29. Greenbelt Act, 2005 Available online: https://www.ola.org/en/legislative-business/bills/parliament-38/session1/bill-135 (accessed on 19 December 2021).

30. Growth Plan for the Greater Golden Horseshoe 2006 । Ontario.Ca Available online: https://www.ontario.ca/document/growth-plan-greater-golden-horseshoe-2006 (accessed on 19 December 2021).

31. Wekerle, G.R.; Sandberg, L.A.; Gilbert, L.; Binstock, M. Nature as a Cornerstone of Growth: Regional and Ecosystems Planning in the Greater Golden Horseshoe. Canadian Journal of Urban Research 2007, 16, 20-38.

32. Cadieux, K.V.; Taylor, L.E.; Bunce, M.F. Landscape Ideology in the Greater Golden Horseshoe Greenbelt Plan: Negotiating Material Landscapes and Abstract Ideals in the City's Countryside. Journal of Rural Studies 2013, 32, 307-319, doi:10.1016/j.jrurstud.2013.07.005.

33. Newbold, K.B.; Scott, D. Migration, Commuting Distance, and Urban Sustainability in Ontario's Greater Golden Horseshoe: Implications of the Greenbelt and Places to Grow Legislation. The Canadian Geographer / Le Géographe canadien 2013, 57, 474-487, doi:10.1111/j.1541-0064.2013.12044.x.

34. Ontario Federation of Agriculture. 2019. Small Solar. Ontario Federation of Agriculture. https://ofa.on.ca/resources/small-solar/ (accessed on 18 December 2021).

35. Dupraz, C.; Marrou, H.; Talbot, G.; Dufour, L.; Nogier, A.; Ferard, Y. Combining Solar Photovoltaic Panels and Food Crops for Optimising Land Use: Towards New Agrivoltaic Schemes. Renewable Energy 2011, 36, 2725-2732, doi:10.1016/j.renene.2011.03.005.

36. Mavani, D.D.; Chauhan, P.M.; Joshi, V. Beauty of Agrivoltaic System regarding double utilization of same piece of land for Generation of Electricity \& Food Production. Int. J. Sci. Eng. Res. 2019, 10, 118-148.

37. Dinesh, H.; Pearce, J.M. The potential of agrivoltaic systems. Renew. Sustain. Energy Rev. 2016, 54, $299-308$. doi:10.1016/j.rser.2015.10.024.

38. Santra, P.; Pande, P.C.; Kumar, S.; Mishra, D.; Singh, R.K. Agri-voltaics or Solar farming- the Concept of Integrating Solar PV Based Electricity Generation and Crop Production in a Single Land use System. Int. J. Renew. Energy Res. 2017, 7, 694-699.

39. Guerin, T.F. Impacts and opportunities from large-scale solar photovoltaic (PV) electricity generation on agricultural production. Environ. Qual. Manag. 2019, 28, 7-14, doi:10.1002/tqem.21629.

40. Pascaris, A.S.; Schelly, C.; Burnham, L.; Pearce, J.M. Integrating Solar Energy with Agriculture: Industry Perspectives on the Market, Community, and Socio-Political Dimensions of Agrivoltaics. Energy Res. Soc. Sci. 2021, 75, 102023, doi:10.1016/j.erss.2021.102023.

41. Pascaris, A.S.; Schelly, C.; Pearce, J.M. A First Investigation of Agriculture Sector Perspectives on the Opportunities and Barriers for Agrivoltaics. Agronomy 2020, 10, 1885. https://doi.org/10.3390/agronomy10121885. 
42. Fthenakis, V.M.; Kim, H.C.; Alsema, E. Emissions from Photovoltaic Life Cycles. Environ. Sci. Technol. 2008, 42, 2168-2174, doi: 10.1021/es071763q.

43. Marrou, H.; Wery, J.; Dufour, L.; Dupraz, C. Productivity and radiation use efficiency of lettuces grown in the partial shade of photovoltaic panels. Eur. J. Agron. 2013, 44, 54-66. doi:10.1016/j.eja.2012.08.003.

44. Valle, B.; Simonneau, T.; Sourd, F.; Pechier, P.; Hamard, P.; Frisson, T.; Ryckewaert, M.; Christophe, A. Increasing the Total Productivity of a Land by Combining Mobile Photovoltaic Panels and Food Crops. Applied Energy 2017, 206, 1495-1507, doi:10.1016/j.apenergy.2017.09.113.

45. Barron-Gafford, G.A.; Pavao-Zuckerman, M.A.; Minor, R.L.; Sutter, L.F.; Barnett-Moreno, I.; Blackett, D.T.; Thompson, M.; Dimond, K.; Gerlak, A.K.; Nabhan, G.P.; et al. Agrivoltaics Provide Mutual Benefits across the Food-Energy-Water Nexus in Drylands. Nat Sustain 2019, 2, 848-855, doi:10.1038/s41893-019-0364-5.

46. Hudelson, T.; Lieth, J.H. Crop Production in Partial Shade of Solar Photovoltaic Panels on Trackers. AIP Conference Proceedings 2021, 2361, 080001, doi: $10.1063 / 5.0055174$.

47. Sekiyama, T.; Nagashima, A. Solar Sharing for Both Food and Clean Energy Production: Performance of Agrivoltaic Systems for Corn, A Typical Shade-Intolerant Crop. Environments 2019,6 , 65. doi:10.3390/environments6060065.

48. Trommsdorff, M.; Kang, J.; Reise, C.; Schindele, S.; Bopp, G.; Ehmann, A.; Weselek, A.; Högy, P.; Obergfell, T. Combining Food and Energy Production: Design of an Agrivoltaic System Applied in Arable and Vegetable Farming in Germany. Renewable and Sustainable Energy Reviews 2021, 140, 110694, doi:10.1016/j.rser.2020.110694.

49. Adeh, E.H.; Selker, J.S.; Higgins, C.W. Remarkable Agrivoltaic Influence on Soil Moisture, Micrometeorology and Water-Use Efficiency. PLOS ONE 2018, 13, e0203256, doi:10.1371/journal.pone.0203256.

50. Schindele, S.; Trommsdorff, M.; Schlaak, A.; Obergfell, T.; Bopp, G.; Reise, C.; Braun, C.; Weselek, A.; Bauerle, A.; Högy, P.; et al. Implementation of Agrophotovoltaics: Techno-Economic Analysis of the Price-Performance Ratio and Its Policy Implications. Applied Energy 2020, 265, 114737, doi:10.1016/j.apenergy.2020.114737.

51. Mow, B. Solar Sheep and Voltaic Veggies: Uniting Solar Power and AgriculturelState, Local, and Tribal Governments|NREL [WWW Document], 2018. Available online: https://www.nrel.gov/state-localtribal/blog/posts/solar-sheep-and-voltaic-veggies-uniting-solar-power-and-agriculture.html (accessed on 2 July 2020).

52. Adeh, E.H.; Good, S.P.; Calaf, M. Solar PV Power Potential is Greatest Over Croplands. Sci. Rep. 2019,9 , 11442. https://doi.org/10.1038/s41598-019-47803-3.

53. Elamri, Y.; Cheviron, B.; Lopez, J.-M.; Dejean, C.; Belaud, G. Water Budget and Crop Modelling for Agrivoltaic Systems: Application to Irrigated Lettuces. Agricultural Water Management 2018, 208, 440-453, doi:10.1016/j.agwat.2018.07.001.

54. Al-Saidi, M.; Lahham, N. Solar energy farming as a development innovation for vulnerable water basins. Dev. Pract. 2019, 29, 619-634.

55. Giudice, B.D.; Stillinger, C.; Chapman, E.; Martin, M.; Riihimaki, B. Residential Agrivoltaics: Energy Efficiency and Water Conservation in the Urban Landscape. In Proceedings of the 2021 IEEE Green Technologies Conference (GreenTech); April 2021; pp. 237-244.

56. Miao, R.; Khanna, M. Harnessing Advances in Agricultural Technologies to Optimize Resource Utilization in the Food-Energy-Water Nexus. Annu. Rev. Resour. Econ 2019, 12, 65-85.

57. Martinez, S. Local Food Systems; Concepts, Impacts, and Issues; DIANE Publishing, 2010; ISBN 978-1-4379-3362-8.

58. Brain, R. The Local Food Movement: Definitions, Benefits, and Resources. USU Extension Publication $2012,1-4$.

59. Feenstra, G.W. Local Food Systems and Sustainable Communities. American Journal of Alternative Agriculture 1997, 12, 28-36, doi:10.1017/S0889189300007165.

60. Zhang, P.; Li, W.; Li, S.; Wang, Y.; Xiao, W. Reliability Assessment of Photovoltaic Power Systems: Review of Current Status and Future Perspectives. Applied Energy 2013, 104, 822-833, doi:10.1016/j.apenergy.2012.12.010.

61. Jamil, E.; Hameed, S.; Jamil, B.; Qurratulain Power Quality Improvement of Distribution System with Photovoltaic and Permanent Magnet Synchronous Generator Based Renewable Energy Farm Using Static Synchronous Compensator. Sustainable Energy Technologies and Assessments 2019, 35, 98-116, doi:10.1016/j.seta.2019.06.006.

62. Craciun, B.-I.; Sera, D.; Man, E.A.; Kerekes, T.; Muresan, V.A.; Teodorescu, R. Improved Voltage Regulation Strategies by PV Inverters in LV Rural Networks. In Proceedings of the 2012 3rd IEEE International Symposium on Power Electronics for Distributed Generation Systems (PEDG); June 2012; pp. 775-781.

63. Abdul Kadir, A.F.; Khatib, T.; Elmenreich, W. Integrating Photovoltaic Systems in Power System: Power Quality Impacts and Optimal Planning Challenges. International Journal of Photoenergy 2014, 2014, e321826, doi: $10.1155 / 2014 / 321826$. 
64. Singh, K.; Centurion University of Technology and Management (CUTM), Rajaseetapuram, Odisha - 761211, India; Mishra, S.; Centurion University of Technology and Management (CUTM), Rajaseetapuram, Odisha - 761211, India; Kumar, M.N.; Guru Nanak Institute of Technology (GNIT), Hyderabad - 501506, Telangana, India A Review on Power Management and Power Quality for Islanded PV Microgrid in Smart Village. Indian Journal of Science and Technology 2017, 10, 1-4, doi:10.17485/ijst/2017/v10i17/103033.

65. Saleh, M.S.; Althaibani, A.; Esa, Y.; Mhandi, Y.; Mohamed, A.A. Impact of Clustering Microgrids on Their Stability and Resilience during Blackouts. In Proceedings of the 2015 International Conference on Smart Grid and Clean Energy Technologies (ICSGCE); October 2015; pp. 195-200.

66. Belo, M. Agrivoltaics: Integrating Solar and Agriculture Is a Win-Win Available online: https://blog.compassenergyconsulting.ca/agrivoltaics-integrating-solar-and-agriculture-is-a-win-win (accessed on 22 December 2021).

67. Maia, A.S.C.; Culhari, E. de A.; Fonsêca, V. de F.C.; Milan, H.F.M.; Gebremedhin, K.G. Photovoltaic Panels as Shading Resources for Livestock. Journal of Cleaner Production 2020, 258, 120551, doi:10.1016/j.jclepro.2020.120551.

68. Andrew, A.C.; Higgins, C.W.; Smallman, M.A.; Graham, M.; Ates, S. Herbage Yield, Lamb Growth and Foraging Behavior in Agrivoltaic Production System. Front. Sustain. Food Syst. 2021, 0, doi:10.3389/fsufs.2021.659175.

69. Handler, R.; Pearce, J.M. Greener Sheep: Life Cycle Analysis of Integrated Sheep Agrivoltatic Systems. 2021, doi: $10.5281 /$ zenodo.5706110.

70. Ontario Ministry of Agriculture, Food and Rural Affairs. Area, Production and Farm Value of Specified Commercial Vegetable Crops, Ontario Available online: http://www.omafra.gov.on.ca/english/stats/hort/veg all15-16.htm (accessed on 20 December 2021).

71. Ontario Ministry of Agriculture, Food and Rural Affairs. Estimated Area, Yield, Production and Farm Value of Specified Field Crops, Ontario (Imperial and Metric Units) Available online: http://www.omafra.gov.on.ca/english/stats/crops/estimate new.htm (accessed on 21 December 2021).

72. Macrotrends. Wheat Prices - 40 Year Historical Chart Available online: https://www.macrotrends.net/2534/wheatprices-historical-chart-data (accessed on 20 December 2021).

73. Lytle, W.; Meyer, T.K.; Tanikella, N.G.; Burnham, L.; Engel, J.; Schelly, C.; Pearce, J.M. Conceptual Design and Rationale for a New Agrivoltaics Concept: Pasture-Raised Rabbits and Solar Farming. Journal of Cleaner Production 2021, 282, 124476, doi:10.1016/j.jclepro.2020.124476.

74. System Advisor Model (SAM); National Renewable Energy Laboratory, 2021; https://github.com/NREL/SAM (accessed on 6 November 2021).

75. Ontario Energy Quarterly: Electricity in Q1 2020 Available online: http://www.ontario.ca/page/ontario-energyquarterly-electricity-q1-2020 (accessed on 21 December 2021).

76. City of Toronto. (2001). (rep.). Powers of Canadian Cities - The Legal Framework. Available online: https://www.toronto.ca/ext/digital comm/inquiry/inquiry site/cd/gg/add pdf/77/Governance/Electronic Docum ents/Other CDN Jurisdictions/Powers of Canadian Cities.pdf

77. Greenbelt Designation Available online: https:/geohub.lio.gov.on.ca/datasets/greenbelt-designation/explore (accessed on 18 December 2021).

78. Government of Ontario. (2020). Provincial Policy Statement, 2020. Retrieved December 17, 2021, from https://files.ontario.ca/mmah-provincial-policy-statement-2020-accessible-final-en-2020-02-14.pdf

79. Government of Ontario. (2020). A Place to Grow: Growth Plan for the Greater Golden Horseshoe. Retrieved December 17, 2021, from https://files.ontario.ca/mmah-place-to-grow-office-consolidation-en-2020-08-28.pdf

80. Government of Ontario. (2017). Greenbelt Plan. Retrieved December 17, 2021, from https://files.ontario.ca/greenbelt-plan-2017-en.pdf

81. Government of Canada, CER,(2020). Canada's Adoption of Renewable Power Sources - Energy Market Analysis. Canada Energy Regulator. Retrieved December 17, 2021, from https://www.cer-rec.gc.ca/en/data-analysis/energycommodities/electricity/report/2017-canadian-adoption-renewable-power/canadas-adoption-renewable-powersources-energy-market-analysis-solar.html

82. Ontario Energy Quarterly: Electricity in Q4 2020 Available online: http://www.ontario.ca/page/ontario-energyquarterly-electricity-q4-2020 (accessed on 18 December 2021).

83. Geerts, H.; Robertson, A.; Ontario; Ministry of Agriculture, F. and R.A. Guidelines on Permitted Uses in Ontario's Prime Agricultural Areas; 2016; ISBN 978-1-4606-8529-7.

84. Government of Ontario. (2017). Greenbelt Plan. Retrieved December 17, 2021, from https://files.ontario.ca/greenbelt-plan-2017-en.pdf

85. Government of Ontario. (2020). Provincial Policy Statement, 2020. Retrieved December 17, 2021, from https://files.ontario.ca/mmah-provincial-policy-statement-2020-accessible-final-en-2020-02-14.pdf 
86. Hayibo, K.S.; Pearce, J.M. A Review of the Value of Solar Methodology with a Case Study of the U.S. VOS. Renewable and Sustainable Energy Reviews 2021, 137, 110599, doi:10.1016/j.rser.2020.110599.

87. Weaver, J.F. All I Want for Christmas Is a Solar-Powered Greenhouse Available online: https://pv-magazineusa.com/2021/12/24/all-i-want-for-christmas-is-a-solar-powered-greenhouse/ (accessed on 26 December 2021).

88. Ravi, S.; Macknick, J.; Lobell, D.; Field, C.; Ganesan, K.; Jain, R.; Elchinger, M.; Stoltenberg, B. Colocation Opportunities for Large Solar Infrastructures and Agriculture in Drylands. Applied Energy 2016, 165, 383-392, doi:10.1016/j.apenergy.2015.12.078.

89. Pringle, A.M.; Handler, R.M.; Pearce, J.M. Aquavoltaics: Synergies for dual use of water area for solar photovoltaic electricity generation and aquaculture. Renew. Sustain. Energy Rev. 2017, 80, 572-584.

90. Thompson, E.P.; Bombelli, E.L.; Shubham, S.; Watson, H.; Everard, A.; D'Ardes, V.; Schievano, A.; Bocchi, S.; Zand, N.; Howe, C.J.; et al. Tinted Semi-Transparent Solar Panels Allow Concurrent Production of Crops and Electricity on the Same Cropland. Advanced Energy Materials 2020, 10, 2001189, doi:10.1002/aenm.202001189.

91. Weselek, A.; Bauerle, A.; Zikeli, S.; Lewandowski, I.; Högy, P. Effects on Crop Development, Yields and Chemical Composition of Celeriac (Apium Graveolens L. Var. Rapaceum) Cultivated Underneath an Agrivoltaic System. Agronomy 2021, 11, 733, doi:10.3390/agronomy11040733.

92. Amaducci, S.; Yin, X.; Colauzzi, M. Agrivoltaic systems to optimize land use for electric energy production. Appl. Energy 2018, 220, 545-561. doi:10.1016/j.apenergy.2018.03.081.

93. Malu, P.R.; Sharma, U.S.; Pearce, J.M. Agrivoltaic potential on grape farms in India. Sustain. Energy Technol. Assess. 2017, 23, 104-110.

94. Marrou, H.; Guilioni, L.; Dufour, L.; Dupraz, C.; Wéry, J. Microclimate under agrivoltaic systems: Is crop growth rate affected in the partial shade of solar panels? Agric. For. Meteorol. 2013, 177, 117-132.

95. Riaz, M.H.; Imran, H.; Alam, H.; Alam, M.A.; Butt, N.Z. Crop-Specific Optimization of Bifacial PV Arrays for Agrivoltaic Food-Energy Production: The Light-Productivity-Factor Approach. arXiv 2021, arXiv:2104.00560.

96. PFAF. Edible Uses. Available online: https://pfaf.org/user/edibleuses.aspx (accessed on 20 September 2021).

97. Katsikogiannis, A. Integration of Bifacial PV in Agrivoltaic Systems: A Synergistic Design Approach. 2021. http://resolver.tudelft.nl/uuid:9a5e0536-b96d-4294-80e9-453b2a411ffe

98. Martín-Chivelet, N.; Guillén, C.; Trigo, J.F.; Herrero, J.; Pérez, J.J.; Chenlo, F. Comparative Performance of SemiTransparent PV Modules and Electrochromic Windows for Improving Energy Efficiency in Buildings. Energies 2018, 11, 1526. https://doi.org/10.3390/en11061526.

99. Yeop Myong, S.; Won Jeon, S. Design of Esthetic Color for Thin-Film Silicon Semi-Transparent Photovoltaic Modules. Solar Energy Mater. Sol. Cells 2015, 143, 442-449, doi:10.1016/j.solmat.2015.07.042.

100. Yano, A.; Onoe, M.; Nakata, J. Prototype Semi-Transparent Photovoltaic Modules for Greenhouse Roof Applications. Biosyst. Eng. 2014, 122, 62-73, doi:10.1016/j.biosystemseng.2014.04.003.

101. Li, Z.; Yano, A.; Cossu, M.; Yoshioka, H.; Kita, I.; Ibaraki, Y. Electrical Energy Producing Greenhouse Shading System with a Semi-Transparent Photovoltaic Blind Based on Micro-Spherical Solar Cells. Energies 2018, $11,1681$.

102. Li, Z.; Yano, A.; Cossu, M.; Yoshioka, H.; Kita, I.; Ibaraki, Y. Shading and Electric Performance of a Prototype Greenhouse Blind System Based on Semi-Transparent Photovoltaic Technology. J. Agric. Meteorol. 2018, 74, 114122.

103. Li, Z.; Yano, A.; Yoshioka, H. Feasibility Study of a Blind-Type Photovoltaic Roof-Shade System Designed for Simultaneous Production of Crops and Electricity in a Greenhouse. Appl. Energy 2020, 279, 115853.

104. Thompson, E.P.; Bombelli, E.L.; Shubham, S.; Watson, H.; Everard, A.; D'Ardes, V.; Schievano, A.; Bocchi, S.; Zand, N.; Howe, C.J.; et al. Tinted Semi-Transparent Solar Panels Allow Concurrent Production of Crops and Electricity on the Same Cropland. Adv. Energy Mater. 2020, 10, 2001189, doi:10.1002/aenm.202001189.

105. Shen, L.; Lou, R.; Park, Y.; Guo, Y.; Stallknecht, E.J.; Xiao, Y.; Rieder, D.; Yang, R.; Runkle, E.S.; Yin, X. Increasing Greenhouse Production by Spectral-Shifting and Unidirectional Light-Extracting Photonics. Nat Food 2021, 2, 434441, doi:10.1038/s43016-021-00307-8.

106. Timmermans, G.H.; Hemming, S.; Baeza, E.; van Thoor, E.A.J.; Schenning, A.P.H.J.; Debije, M.G. Advanced Optical Materials for Sunlight Control in Greenhouses. Adv. Opt. Mater. 2020, 8, 2000738, doi:10.1002/adom.202000738.

107. Sánchez-Lanuza, M.B.; Menéndez-Velázquez, A.; Peñas-Sanjuan, A.; Navas-Martos, F.J.; Lillo-Bravo, I.; DelgadoSánchez, J.-M. Advanced Photonic Thin Films for Solar Irradiation Tuneability Oriented to Greenhouse Applications. Materials 2021, 14, 2357. https://doi.org/10.3390/ma14092357.

108. Shen, L.; Yin, X. Increase Greenhouse Production with Spectral-Shifting and Unidirectional Light-Extracting Photonics. In Proceedings of the New Concepts in Solar and Thermal Radiation Conversion IV, SPIE, San Diego, CA, USA, 1-5 August 2021; Volume 11824, p. 1182402. 
109. Agricultural Adaptation Council. "Waste” Light Can Lower Greenhouse Production Costs. Greenhouse Canada, 30 December 2019.

110. Growing Trial for Greenhouse Solar Panels - Research \& Innovation I Niagara College. Research \& Innovation 2019. Available online: https:/www.ncinnovation.ca/blog/research-innovation/growing-trial-for-greenhouse-solarpanels (accessed on 25 Oct. 2021).

111. Chiu, G. Dual Use for Solar Modules. Greenhouse Canada 2019. Available online: https://www.greenhousecanada.com/technology-issues-dual-use-for-solar-modules-32902/ (accessed on 25 Oct. 2021).

112. El-Bashir, S.M.; Al-Harbi, F.F.; Elburaih, H.; Al-Faifi, F.; Yahia, I.S. Red Photoluminescent PMMA Nanohybrid Films for Modifying the Spectral Distribution of Solar Radiation inside Greenhouses. Renew. Energy 2016, 85, 928938, doi:10.1016/j.renene.2015.07.031.

113. Parrish, C.H.; Hebert, D.; Jackson, A.; Ramasamy, K.; McDaniel, H.; Giacomelli, G.A.; Bergren, M.R. Optimizing Spectral Quality with Quantum Dots to Enhance Crop Yield in Controlled Environments. Commun. Biol. 2021, 4, 124, doi:10.1038/s42003-020-01646-1.

114. UbiGro A Layer of Light. Available online: https://ubigro.com/case-studies (accessed on 22 September 2021).

115. Pearce, J.M. Parametric Open Source Cold-Frame Agrivoltaic Systems. Inventions 2021,6 , 71. https://doi.org/10.3390/inventions6040071

116. Cohn, J.P. Citizen Science: Can Volunteers Do Real Research? BioScience 2008, 58, 192-197, doi:10.1641/B580303.

117. Bonney, R.; Cooper, C.B.; Dickinson, J.; Kelling, S.; Phillips, T.; Rosenberg, K.V.; Shirk, J. Citizen Science: A Developing Tool for Expanding Science Knowledge and Scientific Literacy. BioScience 2009, 59, 977-984, doi:10.1525/bio.2009.59.11.9.

118. Pascaris, A.S.; Schelly, C.; Rouleau, M.; Pearce, J.M. Do Agrivoltaics Improve Public Support for Solar Photovoltaic Development? Survey Says: Yes! 2021. https://osf.io/preprints/socarxiv/efasx/

119. Tajima, M.; Iida, T. Evolution of Agrivoltaic Farms in Japan. AIP Conference Proceedings 2021, 2361, 030002, doi: $10.1063 / 5.0054674$.

120. Ag. U.Mass. Dual-Use: Agriculture and Solar Photovoltaics Available online: https://ag.umass.edu/cleanenergy/fact-sheets/dual-use-agriculture-solar-photovoltaics (accessed on 22 December 2021).

121. Commonwealth of Massachusetts, Executive Office of Energy and Environmental Affairs, DEPARTMENT OF ENERGY RESOURCES, DEPARTMENT OF AGRICULTURAL RESOURCES, SOLAR MASSACHUSETTS RENEWABLE TARGET PROGRAM, (225 CMR 20.00), GUIDELINE, Guideline Regarding the Definition of Agricultural Solar Tariff Generation Units, Effective Date: April 26, 2018

https://www.mass.gov/doc/agricultural-solar-tariff-generation-units-guideline-final/download (accessed on 22 December 2021).

122. Levey, B.; Detterman, B.; Jacobs, H. Massachusetts SMART Program Regulations: More Solar Capacity, Less Land Area Available online: https://www.bdlaw.com/publications/massachusetts-smart-program-regulations-moresolar-capacity-less-land-area/ (accessed on 22 December 2021).

123. DIN SPEC 91434:2021-05, Agri-Photovoltaik-Anlagen_- Anforderungen an Die Landwirtschaftliche Hauptnutzung Beuth Verlag GmbH;

124. Ouzts, E.; August 28, E.N.N.; 2017 Farmers, Experts: Solar and Agriculture 'Complementary, Not Competing' in North Carolina Available online: http://energynews.us/2017/08/28/farmers-experts-solar-and-agriculturecomplementary-not-competing-in-north-carolina/ (accessed on 22 December 2021).

125. Amelinckx, A. Solar Power and Honey Bees Make a Sweet Combo in Minnesota. Smithsonian Magazine, Available online: https://www.smithsonianmag.com/innovation/solar-power-and-honey-bees-180964743/ (accessed on 22 December 2021).

126. Use of Electricity - U.S. Energy Information Administration (EIA) Available online: https://www.eia.gov/energyexplained/electricity/use-of-electricity.php (accessed on 21 December 2021).

127. Government of Canada, C.E.R. NEB - Market Snapshot: Canadian Electricity Exports to the U.S. Focused on Renewable Power Exports to Specific Markets Available online: https://www.cer-rec.gc.ca/en/dataanalysis/energy-markets/market-snapshots/2017/market-snapshot-canadian-electricity-exports-u-s-focusedrenewable-power-exports-specific-markets.html (accessed on 18 December 2021).

128. Government of Canada, C.E.R. NEB - Provincial and Territorial Energy Profiles - Ontario Available online: https://www.cer-rec.gc.ca/en/data-analysis/energy-markets/provincial-territorial-energy-profiles/provincialterritorial-energy-profiles-ontario.html (accessed on 18 December 2021).

129. State Carbon Dioxide Emissions Data - U.S. Energy Information Administration (EIA) Available online: https://www.eia.gov/environment/emissions/state/index.php (accessed on 18 December 2021). 
130. Prehoda, E.W.; Pearce, J.M. Potential Lives Saved by Replacing Coal with Solar Photovoltaic Electricity Production in the U.S. Renewable and Sustainable Energy Reviews 2017, 80, 710-715, doi:10.1016/j.rser.2017.05.119.

131. Agriculture Canada. Statistical Overview of the Canadian Vegetable Industry 2019 Available online: https://agriculture.canada.ca/en/canadas-agriculture-sectors/horticulture/horticulture-sector-reports/statisticaloverview-canadian-vegetable-industry-2019 (accessed on 20 December 2021).

132. Agri-Food Exports by Sector. Canadian Agri-Food Trade Alliance. Available online: https://cafta.org/agri-foodexports/cafta-exports/ (accessed on 20 December 2021). 